Toutes ces suggestions, ces idées constructives, se rencontreront bientôt; elles seront coordonnées afin de former un seul rapport homogène, et couvrant à peu près toutes les possibilités de rétablissement d'après-guerre qui constitueront un actif pour l'économie de la Province.

Je ne sais si je puis me permettre cette indiscrétion, mais voici les prin. cipaux points qui ont retenu l'attention des forestiers du Québec:

(1) Développement de la voirie forestière;

(2) Protection de la forêt, à tous points de vue;

(3) Finance forestière pour faciliter l'exploitation et l'industrie forestière;

(4) Aménagement sylvicole;

(5) Education et entraînement forestier.

Vous êtes tous des techniciens, peut-être aussi des experts forestiers; vous savez donc que notre plan de travail comporte des développements infinis.

Puissent quelques réalisations pratiques couronner nos efforts et nos recherches; nous aurons alors contribué à gagner une paix véritable pour notre province et notre Canada.

\title{
POST-WAR FORESTRY PLANS IN ONTARIO
}

\author{
By J. A. BRodie \\ Ontario Forests Branch, Toronto, Ontario.
}

$\mathrm{T}$

$\checkmark$ HE IMPORTANCE of forests and forest industries to Canadian life is apparent to those of us who, in our professional life, live close to the forests and deal with their problems daily. We are sometimes impatient to note the lack of appreciation of the problems and potentialities by the general public. To this lack of public understanding and appreciation we ascribe many of our difficulties in obtaining support for our program of forest management. However, we must as professional men lay our plans soundly and well and present to the public a well-thought-out and technically sound series of projects clearly indicating our step by step objectives capable of attracting and holding public support on an increasing scale as years go by. As professional men this must always be our main objective. I sometimes think that our planning in Forestry has been more idealistic than realistic; truly one visualizes imaginatively a structure before commencing drawing the detailed plans and specifications and prepares the estimates. In Forestry we visualized the general plan in an idealistic imaginative manner, presented concrete evidence in the way of statistics of the value of forests to our economic life, pointed out the dire consequence of further depletion, but far too frequently become vague and argumentative about the basic plans and estimates for the structure. We urge a plan of forest management but let us remember that the managed forest is the final structure. Are we now in a position to lay down the necessary plans for a managed forest that will attract the purchaser-the public. Everyone will admit that a fairly lengthy period of research, investigation and experimentation must intervene before 
the plans can be drawn up. We will, therefore, if we are wise, accept lesser and more clearly discernible objectives. Should we not stress at present the elimination of waste in our forests-waste due to fire, insects and fungi, over-maturity of timber stands due to limited transportation facilities, waste in logging and in the process of manufacturing-and at the same time proceed more quietly with our research and experimenting on how to grow timber?

In the depression years concluded by the outbreak of war it may be argued that in Canada we missed a splendid opportunity to utilize spare Canadian manpower for improvement of our forests. There is now lying plainly before us a similar opportunity to use spare Canadian manpower to improve our forests. Post-war plans are now our second most important national undertaking and may within a reasonable period attain highest priority.

Post-war plans will have three main objectives:

1. Re-training of men for civilian occupations;

2. The creation of assets which will give widely increased opportunities for profitable employment;

3. The profitable employment of men during the critical readjustment period.

Forestry presents two great advantages in rehabilitation: one, that there is much ready-made work which may be undertaken at once, especially in forest fire protection improvements, and the other, that time and money spent in this direction is the best investment which could be made. It will provide employment in the future.

It will be necessary to superimpose a post-war administrative structure of staff on that of the existing organization of the Department of Lands and Forests for a period of about four years. This will have to be much larger than the existing organization and its personnel will be largely drawn from the new work group itself. At the termination of the rehabilitation program several hundreds of men may be retained permanently to supply the need for an augmented staff.

The Province divides itself naturally into two regions with respect to this subject-the Crown forest of Northern Ontario and the agricultural section of Southern Ontario, each of which has its own particular problems.

The main problem in Northern Ontario is to place under proper forest management the extensive area of timber land lying north of the Southern Agricultural region. It is desirable that an improved forest protection system be built up, and that a systematic management plan be adopted in timber cutting.

\section{Protection Measures}

Following the last war the Province commenced a program of permanent forest fire protection improvements. This program was interrupted in turn by the depression and the war. It is hoped that in the four year period following the war all of the slack will be picked up; that is, twenty years of work would be completed in a four year period. 
The improvements needed may be divided under the heads of Transportation, Housing (buildings), Communication, Detection and Prevention.

Transportation. One of the greatest problems of fire protection is to get men and equipment rapidly to the scene of fires in the great spaces of the north country. A considerable addition to the mileage of secondary roads, portages and trails is urgently needed. As well as the construction of new roads and trails, many of those closed through lack of use in war-time will require improving. Water transportation must also be improved primarily by the clearance of streams and dam building.

Housing. To provide accommodation for staff, equipment and supplies, including workshops to operate the entire forest protection system, a considerable amount of building is required.

Communication. The principal means of communication is by telephone. The present system of 4,300 miles of line gives about 65 per cent of adequate coverage. In addition to bringing this up to 100 per cent, about 800 miles of line requires rebuilding.

Detection. Detection is accomplished largely by means of a system of $80 \mathrm{ft}$. and $100 \mathrm{ft}$. steel lookout towers. To give effective coverage about 100 additional towers will be built. There are now 224 in use.

Prevention. The prevention work projects which may be undertaken include removal of hazards along highways, roads in particularly hazardous locations and the preparation of camp sites to provide safety from fire spread.

The above fire protection program would call for the initial employment of approximately 5,000 men in the first year, 2,500 men in the second, 1,250 in the third and 625 in the fourth. The latter number may be retained permanently to operate the improved system. It is recognized that, if the Dominion authorities ask the Department to employ a much larger number of men, there will be plenty of work available, particularly in general fire hazard removal and in road and trail construction. The number of men who may be employed could be readily doubled, if they need work.

\section{Forest Management}

To secure a sound foundation for practice, forest management surveys, which aim to develop industrial communities founded on wood, should be undertaken. Inventories of growing stock and regeneration studies of some species are needed. Economic research is indicated to solve some of the vexing problems of utilization. Brush burning projects seem desirable in some localities. Cultural treatment of young growing stands close to settlements would be advantageous. The above mentioned types of forest management projects, while vitally important, will not serve to employ large. numbers of men. For example, the thirteen forest management surveys in various localities would utilize men in the number of approximately 325,400 , 270 and 210 in the first, second, third and fourth years respectively. Inventories of growing stock would employ 80,40 and 20 men in the second, third and fourth years respectively, following aerial photography in the first year. Regeneration studies would employ $24,24,8$ and 2 in the suc- 
cessive years. The economic studies will call for experts largely, and the four projects contemplated would employ only about $45,10,4$ and 4 in the successive years. The reforestation (planting) project would employ about 120 men in each of the four years and 50 men employed throughout the four year period would meet the requirement of the brush burning project.

\section{REFORESTATION}

Reforestation work in the privately owned forest areas of agricultural Southern Ontario could include planting, seed collecting, nursery practice and silviculture. Unfortunately, planting, which would employ the bulk of the men needed, is of short, seasonal character in the spring and autumn. As continuous employment is desired throughout all of the months of the year, the diffcult problem is presented of devising a balanced program. For example, a program which would undertake to employ say 1,000 men in the planting periods would furnish employment for only about 300 men in the eight-month balance of the year. The availability of a sufficient stock of seedlings, which take a minimum of two years to produce, further complicates the problem. It must be remembered that the normal requirement of seedlings for planting by farmers and other classes of private owners will continue. Any planting projects to be undertaken in Northern Ontario would depend for seedling supply on the same nurseries as the southern projects. It may prove feasible to take the 700 additional men (in the 1,000 figure example) from other types of forest projects in Northern Ontario for the short-term planting projects in Southern Ontario. This plan of organization would presume that the men employed in the northern projects would be agreeable to the shift to southern planting projects.

In conclusion, it may be stressed that the above mentioned Forest Protection, Forest Management and Reforestation work will simply complete a previously projected improvement program, interrupted by the depression and the war. The lack of these normal requirements has adversely affected the efficient administration of the Department.

\section{POST-WAR FORESTRY PLANS IN MANITOBA}

\section{By C. B. GILL ${ }^{1}$}

Senior Forest Engineer, Manitoba Forest Service, Winnipeg, Manitoba.

TV ORK HERE started in May, 1942, with a request from Dr. R. C. Wallace, Chairman of the Sub-Committee on Natural Resources. Plans were started with a double objective,-of employing men and also doing work of national value. Forestry was obviously very suitable for large scale employment which would give future benefits. 